\begin{tabular}{|c|c|c|c|}
\hline VERSITA & GOSPODARKA & SUROWCAMI & MINERALNYMI \\
\hline & Tom 28 & 2012 & Zeszyt 2 \\
\hline
\end{tabular}

EDYTA BRZYCHCZY*

\title{
Proposal of using SWAPs by hard coal mining companies in Poland
}

\section{Introduction}

Running a business entails various risks which can have a significant impact on the economic and production results achieved by a given enterprise. Every economic entity is exposed to, on the one hand, specific risks regardless of the economic sector it operates in and the products it supplies to the market (systemic risk), and on the other, to the specific risk associated with the sector and the way the company operates. Systemic risks include: inflation risk, interest rate risk, currency risk, political risk, market risk. Specific risks include: credit risk, liquidity risk, financial risk, management risk, social risk, legal risk. One way of hedging certain types of risk is to use the appropriately designed financial instruments which make it possible to transfer the risk to the counterparty or share it according to defined rules. Most frequent instruments used for this purpose are derivatives (whose value depends on the value of the underlying instrument) (Bakk 2007). The main derivatives include: forwards, futures, options and swaps (Hull 2012). This article presents the newest group of derivatives, i.e. swaps. The international market in these derivatives currently represents one of the largest and fastest growing segments of the financial market (Leszczyńska 2007). Economic entities use swaps to reduce certain risks associated with their operations. Banks use swaps to reduce their exposure to interest rate and currency risks (McDougall 2001). Industrial companies can in addition reduce the risk of commodity prices changing (James 2003). The history of these instruments is shorter than of other derivatives, as they have basically come to markets in 1980s. Since then, particularly in recent years, they have been

* Ph.D., AGH University of Science and Technology, Faculty of Mining and Geoengineering, Kraków, Poland; e-mail: brzych3@agh.edu.pl 


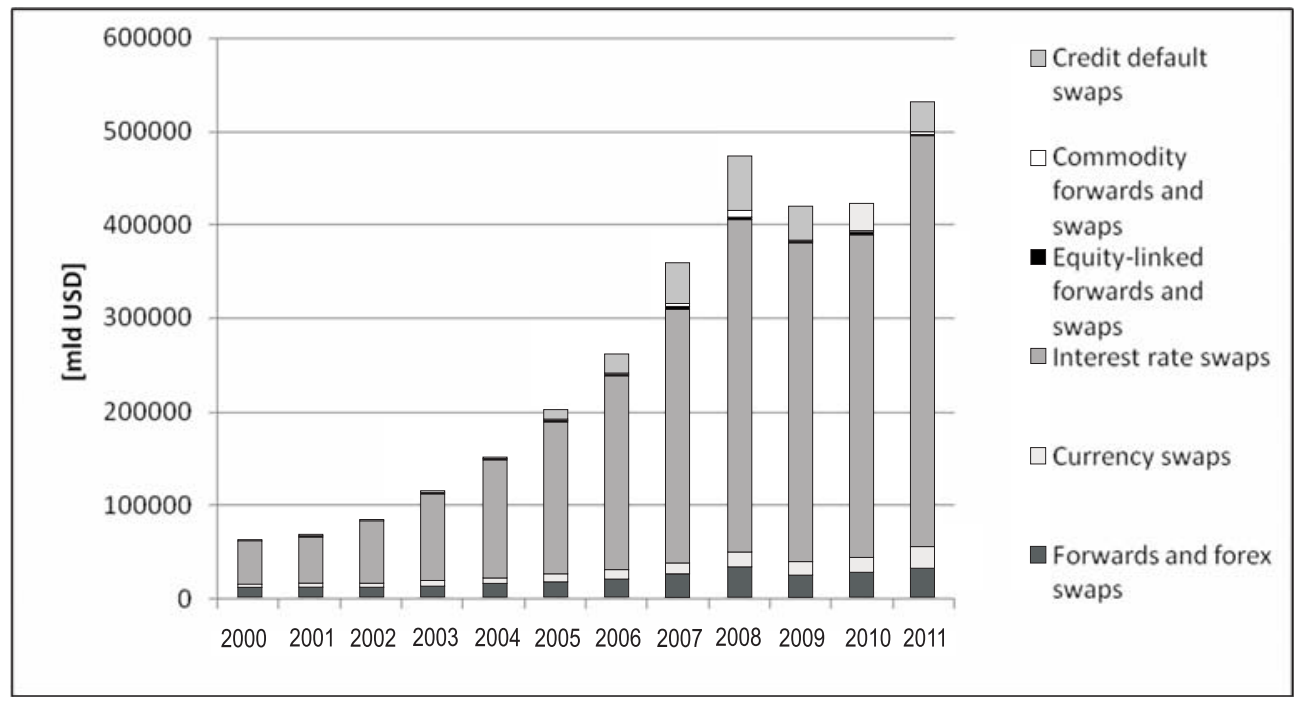

Fig. 1. Nominal value of selected swaps and forwards on the global OTC market Source: own development based on Bank for International Settlements figures

Rys. 1. Wartość nominalna wybranych kontraktów swap i forwards na światowym rynku OTC

growing rapidly (Fig. 1). They have now become the most frequently used risk-transfer instruments (Jajuga, Jajuga 2007).

This article points out the possibilities of swaps being used by Polish mining companies from the hard coal mining sector, which have relatively recently taken their first steps in managing the risk of their operations and in hedging instruments (concerns particularly producers selling a part of their output on the global market).

\section{Characteristics of swaps}

Financial market participants can choose from many different derivatives useful for managing financial risk (e.g. options or futures). Their drawback is that they are traded on exchanges, so they are highly standardised and short of certain flexibility (Instrumenty... 2001). Swaps are traded over the counter (OTC), so companies can conclude contracts that meet their specific needs (tailor-made ones).

A swap is a contract between two parties setting the rules of regular mutual payments whose amounts depend on the level of specified market variables. The contract defines the amount and direction of regular cash flows between the two parties. It also specifies the times when the appropriate market variables are measured (interest rates, exchange rates, commodity prices etc.) (Sopoćko 2005). Payments by either party are calculated based on separate formulas, but are made according to a predefined schedule. This type of swap is called the plain vanilla type. The first party, the so-called fixed leg, intends to stabilise 
a certain market variable, and the second one, referred to as the floating leg, takes over the consequences of the volatility of that market variable (whether favourable or unfavourable)

In a plain vanilla swap, the following have to be defined (Sopoćko 2005):

- the position of each party with regard to the underlying variable of the contract (fixed leg, floating leg),

- the amount of the contract associated with the variable (e.g. the amount of the notional principal or another amount adopted for settlements),

— the defined, fixed payment for the party buying the swap (the fixed leg), called the swap coupon,

- the market quotation representing the current value of the market variable used for settlements (LIBOR, WIBOR, indexes, exchange rates, others),

- payment terms (usually asymmetrical).

Swaps can be used to transfer risks associated with, inter alia (McDougall 2001):

- interest rate changes,

- exchange rate changes,

- commodity price changes,

- share price changes,

- borrower's creditworthiness changes.

The essence of how a swap works will be presented using the example of an interest rate swap (IRS). This type of contract is divided into the following (Leszczyńska 2007):

- coupon swaps,

- basic swaps.

In a coupon swap, one party is paid at a fixed interest rate and the other at the floating interest rate on the same amount. In a basic swap, interest payments calculated at different interest rates are exchanged.

Let us assume that company X has taken out a loan from bank Y (PLN 10,000,000, WIBOR 3M) to upgrade a technology line. As the cost of the loan represents a significant part of the company's operating cost, it has concluded a three-year swap with bank Z, matching this contract to the cash flows of the credit agreement with bank Y (the loan amount, method of interest calculation, payment dates).

Thus:

Notional amount: PLN 10,000,000

Floating rate: WIBOR $3 \mathrm{M}$

Fixed rate: $10 \%$

Payment frequency: semi-annual from Jan. 1, 2006 to Jan. 1, 2009.

A diagram of this deal is shown in Figure 2.

Cash flows between bank $\mathrm{Z}$ and company $\mathrm{X}$ are shown in Table 1 .

The above example shows that when WIBOR rises, company $\mathrm{X}$ receives additional money which offsets the increased interest due to bank Y (calculated at the floating WIBOR $3 \mathrm{M}$ rate). 
90

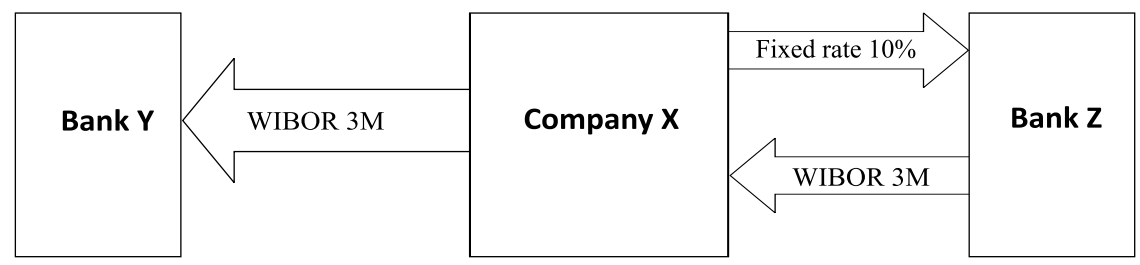

Fig. 2. The diagram of an interest rate swap concluded between company $\mathrm{X}$ and bank $\mathrm{Z}$ Source: own development

Rys.2. Schemat transakcji swapu procentowego pomiędzy przedsiębiorstwem $\mathrm{X}$ a bankiem $\mathrm{Z}$

Cash flows between bank $\mathrm{Z}$ and company $\mathrm{X}$

TABELA 1

Przepływy finansowe pomiędzy bankiem $\mathrm{Z}$ oraz przedsiębiorstwem $\mathrm{X}$

\begin{tabular}{|c|c|c|c|c|c|c||}
\hline Date & $\begin{array}{c}\text { Notional } \\
\text { amount } \\
\text { PLN }\end{array}$ & $\begin{array}{c}\text { Floating } \\
\text { rate } \\
{[\%]}\end{array}$ & $\begin{array}{c}\text { Settlement } \\
\text { amount } \\
\text { PLN }\end{array}$ & $\begin{array}{c}\text { Fixed } \\
\text { rate } \\
{[\%]}\end{array}$ & $\begin{array}{c}\text { Settlement } \\
\text { amount } \\
\text { PLN }\end{array}$ & $\begin{array}{c}\text { Difference } \\
\text { (for party) } \\
\text { PLN }\end{array}$ \\
\hline \hline 1.01 .2006 & $10,000,000$ & 4.61 & & 4.7 & & \\
\hline 1.07 .2006 & $10,000,000$ & 4.20 & 230,500 & 4.7 & 235,000 & $4,500(\mathrm{Z})$ \\
\hline 1.01 .2006 & $10,000,000$ & 4.21 & 210,000 & 4.7 & 235,000 & $25,000(\mathrm{Z})$ \\
\hline 1.07 .2007 & $10,000,000$ & 4.74 & 210,500 & 4.7 & 235,000 & $24,500(\mathrm{Z})$ \\
\hline 1.01 .2007 & $10,000,000$ & 5.60 & 237,000 & 4.7 & 235,000 & $2,000(\mathrm{X})$ \\
\hline 1.07 .2008 & $10,000,000$ & 6.66 & 280,000 & 4.7 & 235,000 & $45,000(\mathrm{X})$ \\
\hline 1.01 .2009 & & & 333,000 & & 235,000 & $98,000(\mathrm{X})$ \\
\hline
\end{tabular}

Source: own development

An interest rate swap, whether coupon or basic, comprises the following elements (Leszczyńska 2007):

1) contract parties,

2) transaction conclusion date,

3) contract currency,

4) notional amount,

5) start and end date,

6) interest payment frequency,

7) date of interest rate fixing,

8) contract prices (interest rates),

9) base for calculating interest payments. 
The interest rate swap shown above belongs to the first generation of financial swaps. This group also includes (Leszczyńska 2007):

- currency swap, FX swap - a contract to buy an amount in a given currency on a specific date at a set exchange rate and then to re-sell the same amount of the same currency at the exchange rate and on the date defined on the day the contract was concluded;

- cross-currency interest rate swap (CIRS) - exchanging the principal of a loan including interest in one currency for the principal of a loan including interest in another currency.

The market of swaps is currently quite well developed. Apart from the contracts listed above, there are many non-standard varieties of swaps. These include (Sopoćko 2005):

- Credit default swap - one party (selling the hedge) receives a certain commission on the value of a loan. In return, it undertakes that if a defined credit event occurs, it will compensate the other party for the losses incurred. The method and dates of payment are detailed in the contract.

- Amortised swap - based on variables whose prices naturally tend to fall (e.g. indexes associated with a group of properties). Their value decreases as they wear out, which is reflected in a fall of the contract amount.

- Accreting swap - based on commodities whose production is seasonal. Between the seasons the unit price of the commodity (and therefore also of the entire contract) rises over time.

- Roller-coaster swap (with a variable contract amount) - associated with periodic changes of prices of commodities or financial instruments, which are reflected in the value of the swap coupon.

- Callable swap, puttable swap - swaps with the right to end the contract before it matures.

- Commodity swap - a transaction in which the parties undertake to exchange, within a defined period, periodic payments calculated based on the prices of a given commodity or a group of commodities.

The above contracts are also referred to as second generation swaps (Leszczyńska 2007).

The most popular swap on the global market is the interest rate swap (IRS). There is a relatively small proportion of swaps associated with equity and of commodity swaps. Market players make quite a lot of use of a relatively new instrument (in existence since 2005 ) i.e. the credit default swap (CDS) [Cf. Fig. 1].

Even though the terms of swaps are negotiated individually, a number of different organisations regulating the trade in these derivatives have been established. The main ones include (Instrumenty... 2001):

- British Bankers Association - BBA,

- International Swap and Derivatives Association - ISDA.

Documents issued by these organisations standardize the conditions and rules of swap trading to some extent. In 1992, the ISDA created a Master Agreement which can be used 
in practically any swap deal. Swaps are usually concluded for between 5 and 10 years on the global market. The transaction currency is usually the US dollar (Leszczyńska 2007).

A significant advantage of this kind of contract is that there is no need to freeze funds in deposits securing it and no fees of any other kind (premiums) that are payable for other derivatives (futures, options). The entity only takes on the risk it is interested in due to the type of business it runs.

The market for this kind of derivatives in Poland is characterised in the next part of this article.

\section{Polish swap market}

The pioneer of swaps in Poland was Polski Bank Rozwoju S.A. which initiated the first FX swap in 1992. Since then, other types of transactions have also featured in the offerings of domestic banks (assets swaps, cross-currency interest rate swaps). Since 1998, a very clear growth in the number of deals on the swap market can be observed, particularly in terms of FX swaps (Leszczyńska 2007).

On the Polish market, swaps are concluded on the primary market and are not traded on a secondary one. Just as the global market, the Polish swap market is an OTC market.

As of the end of 2010, domestic banks maintained the greatest gross off-balance positions in IRS swaps (in interest rate instruments) and in CIRS (in FX instruments) on the OTC derivatives market. This is shown in Table 2 .

The market for IRS has grown rapidly in its net average daily turnover: in 2010, at approx. PLN 1.4bn, it was almost twice as big as in the previous year (Fig. 3).The main parties of these types of deals were Polish banks that used IRS to speculate on interest rate changes by the NBP and to hedge potential losses due to the drop in treasury bond prices. In addition, banks carried out arbitrage strategies on IRS and their treasury bonds (Rozwój... 2011).

In the interest rate derivatives segment, IRS were significant for the Polish financial market due to their number and the value of deals, but also to the exposure of domestic banks to related risk (Fig. 4). Polish banks were much less exposed to the remaining derivatives from this segment (options, bond forwards) in 2010 (Rozwój... 2011).

In the foreign exchange derivative segment, the greatest positions in 2010 resulted from concluding CIRS. The main reason for the increased activity on this market in the last three years (Fig. 5) was a clear change in how Polish banks manage the currency risk resulting from their exposure to mortgage loans in foreign currencies (mainly Swiss francs and euro). The related hedging derivatives were usually non-standardised but with parameters exactly matched to the needs of the parties (Rozwój... 2011). 
Gross positions of Polish banks on the OTC derivatives market as at the end of 2010 (nominal value of instruments in PLN billion)

Pozycje brutto banków krajowych na rynku pozagiełdowych instrumentów pochodnych na koniec $2010 \mathrm{r}$. (wartość nominalna instrumentów w mld zł)

\begin{tabular}{|c|c|c|}
\hline \multirow{2}{*}{ Derivative } & \multicolumn{2}{|c|}{2010} \\
\cline { 2 - 3 } & PLN & other currencies \\
\hline \hline Interest rate derivatives & $1,019.6$ & 160.5 \\
\hline - FRA & 390.2 & 7.8 \\
\hline - IRS & $\mathbf{5 5 7 . 3}$ & $\mathbf{1 3 6 . 3}$ \\
\hline - OIS & 66.0 & 11.3 \\
\hline - options & 3.0 & 4.8 \\
\hline - bond forwards & 2.5 & 0.2 \\
\hline - other & 0.7 & 0.1 \\
\hline Currency instruments & 183.2 & 29.2 \\
\hline - forwards & 58.2 & 5.6 \\
\hline - CIRS & $\mathbf{9 2 . 3}$ & $\mathbf{2 3 . 0}$ \\
\hline - options & 32.7 & 0.5 \\
\hline Equity instruments & 8.7 & 5.7 \\
\hline Credit instruments & 0.1 & 0.0 \\
\hline
\end{tabular}

Source: own development based on (Rozwój systemu finansowego w Polsce w 2010 roku, NBP - Polish Financial System Development, 2010, National Bank of Poland).

Due to the decentralised nature of the OTC market, banks are its makers and main actors. The offering of basic swaps by selected Polish banks is presented in Table 3.

Due to the weak interest in commodity swaps, only a few banks offer them. One of the first swaps of this kind was offered by BRE Bank SA in 2005. The offer was to hedge deals in raw materials: base metals, coal, plastics or petroleum products. With the exception of restrictions concerning the list of commodities and the transaction value (USD 100,000), the remaining elements of the contract, i.e. the settlement terms, duration or price structure were tailored to the customer's needs (eGospodarka 2005).

Banks have so far been and will probably remain the main actors of the swap market. Their significance in this and other markets is due to their experience and the equipment used to efficiently trade derivatives (including their IT platforms). In certain conditions, it is cost-effective to use specialised institutions, called swap brokers. Their job includes finding the counterparty for a specific deal and negotiating deal elements. Yet the role of brokers is much smaller than of swap dealers, who, apart from intermediating, actively participate in the contract (are a party to it) (Sopoćko 2005). Neither are deals between any two entities ruled 
94

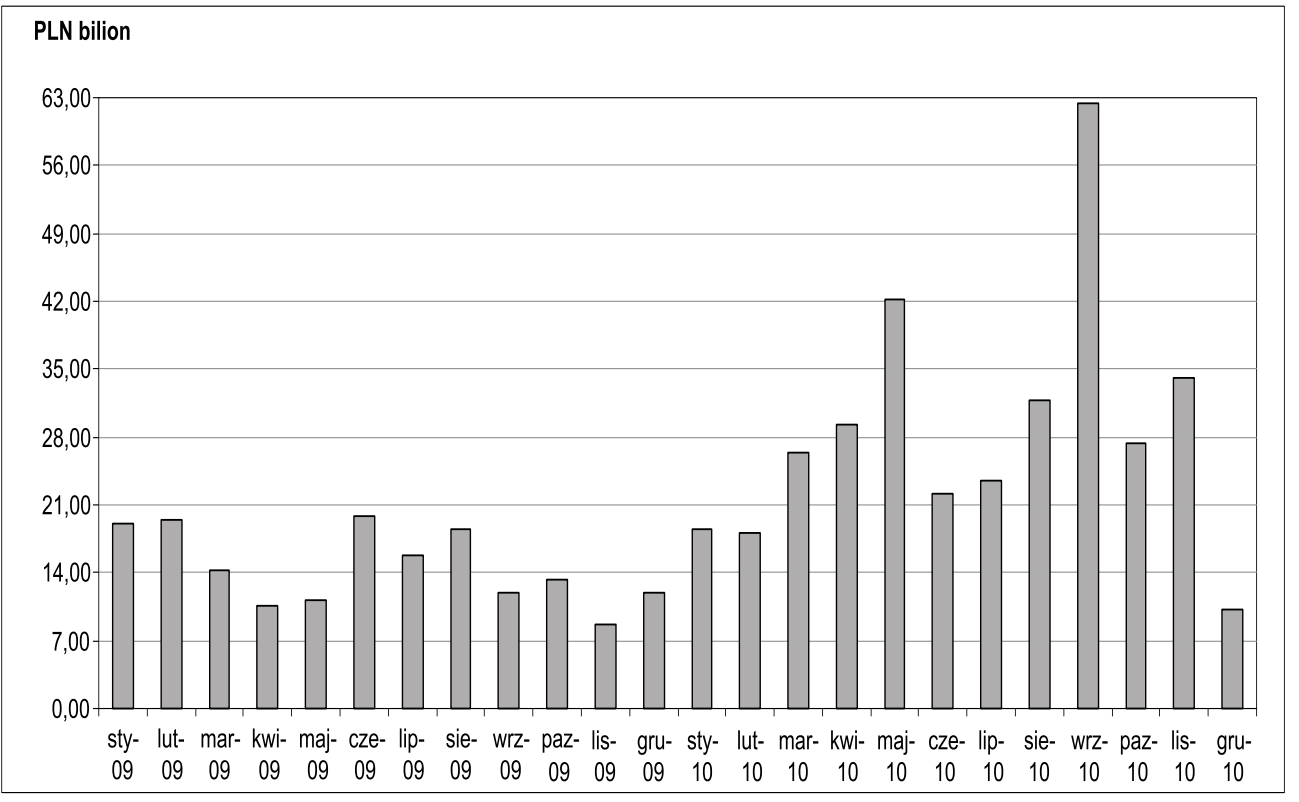

Fig. 3. Monthly net turnover on the Polish market of PLN-denominated IRS, 2009-2010 Source: Rozwój systemu finansowego w Polsce w 2010 roku

Rys. 3. Miesięczne obroty netto na krajowym rynku transakcji IRS nominowanych w złotych w latach 2009-2010

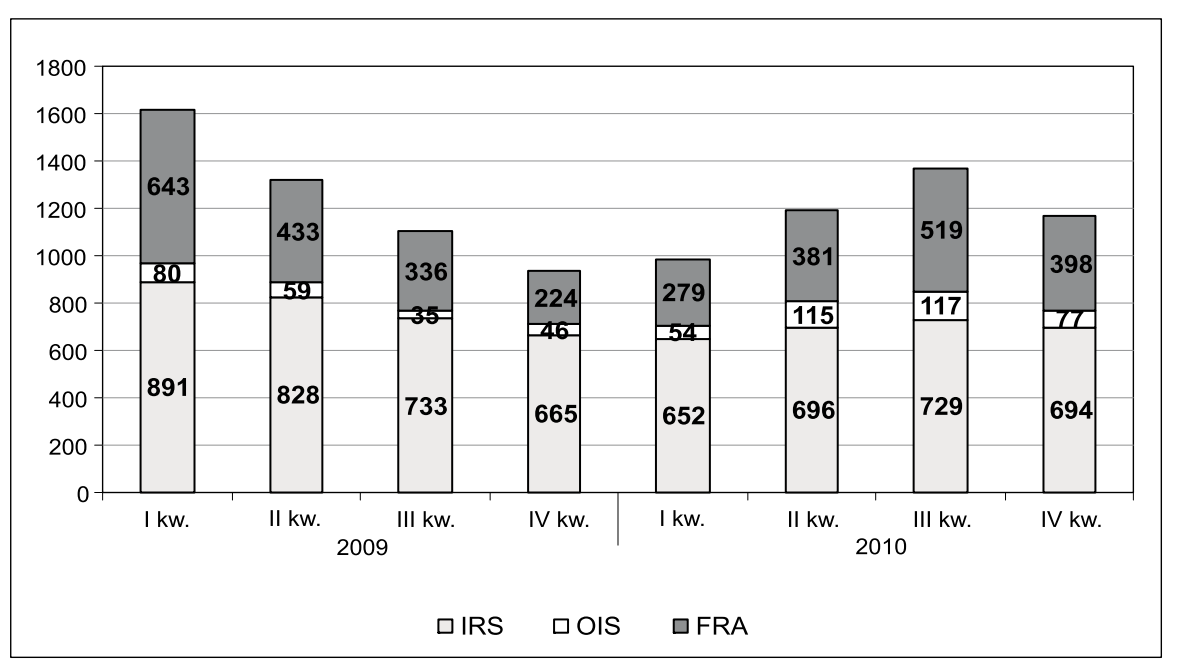

Fig. 4. Gross positions of Polish banks on the OTC market of interest rates derivatives in 2009-2010 (nominal value of instruments in PLN billion)

Source: (Rozwój systemu finansowego w Polsce w 2010 roku)

Rys. 4. Pozycje brutto banków krajowych na rynku pozagiełdowych instrumentów pochodnych na stopę procentową w latach 2009-2010 (wartość nominalna instrumentów, w mld zł) 


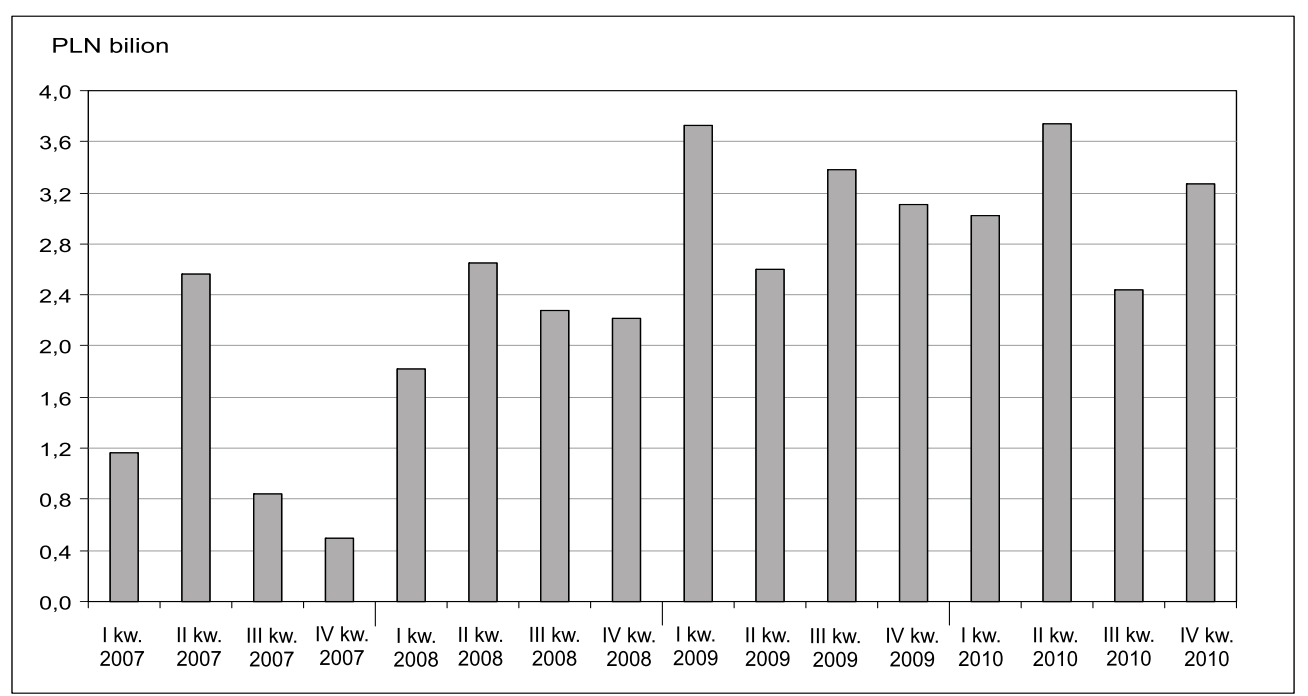

Fig. 5. Net monthly average turnover on the market of FX/PLN CIRS (interbank market) in 2007-2010 Source: Rozwój systemu finansowego w Polsce w 2010 roku

Rys. 5. Średnie miesięczne obroty netto na rynku transakcji CIRS waluta obca/złoty (rynek międzybankowy) w latach 2007-2010

The offering of swaps by selected Polish banks

Oferta wybranych banków krajowych w zakresie kontraktów swap

\begin{tabular}{|l|c|c|c||}
\hline \multicolumn{1}{|c|}{ Bank } & FX swaps & IRS & CIRS \\
\hline \hline Bank Gospodarki Żywnościowej S.A & $\mathrm{X}$ & & \\
\hline Bank Handlowy w Warszawie S.A. & $\mathrm{X}$ & $\mathrm{X}$ & $\mathrm{X}$ \\
\hline Bank Ochrony Środowiska S.A. & $\mathrm{X}$ & & \\
\hline Bank PKO S.A. & $\mathrm{X}$ & & \\
\hline Bank Przemysłowo-Handlowy S.A. & $\mathrm{X}$ & & $\mathrm{X}$ \\
\hline Bank Zachodni WBK S.A. & $\mathrm{X}$ & $\mathrm{X}$ & \\
\hline BNP Paribas Bank (Polska) S.A. & $\mathrm{X}$ & & $\mathrm{X}$ \\
\hline BRE Bank S.A. & $\mathrm{X}$ & $\mathrm{X}$ & \\
\hline Fortis Bank Polska S.A. & $\mathrm{X}$ & & \\
\hline ING Bank Śląski S.A. & $\mathrm{X}$ & $\mathrm{X}$ & \\
\hline Kredyt Bank S.A. & $\mathrm{X}$ & & \\
\hline PKO BP & $\mathrm{X}$ & & \\
\hline PBK S.A. & $\mathrm{X}$ & & \\
\hline Raiffeisen Bank Polska S.A. & $\mathrm{X}$ & & \\
\hline
\end{tabular}

Source: own development based on (Leszczyńska 2007) 
out. The Polish law calls for no special formalities associated with concluding a swap contract. These contracts are governed by the Civil Code (Leszczyńska 2007).

\section{Use of swaps by mining companies}

In their financial statements, global mining corporations (Rio Tinto, Vale, Anglo American, BHP Billiton) all report the following most important risks for their business: interest rate risk, currency risk and the risk of product prices changing. In their activity (not only hedging), they use contracts including the following:

- IRS (based on EURIBOR, LIBOR - e.g. Vale, Rio Tinto, Anglo American, Xstrata),

- CIRS (Rio Tinto, Anglo American, Vale),

- FX swaps (BHP Billiton, Vale),

- commodity swaps (Xstrata - gold, Vale - natural gas, electricity).

Of Polish mining companies, KGHM PolskaMiedź S.A. is the most experienced financial market player as it has used various derivatives for more than a dozen years. This company uses swaps to a limited extent, namely commodity swaps for copper (trading instruments). The main instruments it hedges its copper price with are options. In 2010, KGHM reported swaps/forwards for $250 \mathrm{Mg}$ of copper worth USD 9,086 Mg (Sprawozdanie... 2010).

Mining companies producing hard coal have not been active on the swap market yet. The area they hedge using derivatives is mainly currency risk. For this purpose, these companies use FX options and forwards. To hedge the coal price on the global or domestic market, mining companies could use:

- Coal futures - a relatively new instrument listed on NYMEX (Magda 2010). There are both advantages to using it (easily negotiable, secured by numerous requirements for deal parties) and disadvantages (a deposit required, standardization). It is not designed for individual requirements deviating from the standards adopted.

- Forwards - a contract to supply/purchase a specific quantity of coal at a pre-set price. The characteristic feature of these contracts is that parties undertake to perform them regardless of the financial consequences the parties have to bear.

- Commodity swap - can form an interesting alternative or a supplement to the contracts listed above (a swap treated as a series of forwards without the need for physical delivery). Unlike a forward, this swap will generate multiple cash flows at specified times and can therefore make it easier to raise additional capital and also to more effectively manage corporate finance. The term of the swap should correspond to the individual needs of the enterprise concerning the term of exposure to risk and should take into account certain regular events occurring in the global economy (business cycles). An example of how this type of instrument could be used by a mining company exporting steam coal to the global market is presented below in this article. 
The coal swaps on global market are mainly settled against either the API2, API4 or globalCOAL FOB NEWC indices. API2 (All Published Index number 2) is the biggest coal derivatives market for CIF ARA (Amsterdam, Rotterdam and Antwerp) coal, delivered into Europe and inclusive of freight costs and insurance. API4, for South African free on board (FOB) coal is the second largest market. The globalCOAL FOB Newc market, for Australian coal, is the most recent to emerge, and while only accounting for around $5 \%$ of the total derivatives market, it is growing year-on-year. The API2 index is an estimate of the current 90-day price for steam coal delivered into Europe and the API4 index, are calculated by various publishers. The FOB Newc index is based on actual deals, bids and offers registered on the globalCOAL trading screen for the underlying physical Newcastle coal product (Platts.com).

The purpose of mining company $\mathrm{X}$ is to limit the risk of coal price changing within a certain time period. The company can, therefore, buy a forward for coal delivery at a specific place, time and price (e.g. Argus Forward Coal Prices). In addition, it can hedge its possible losses due to rising coal prices and the obligation to sell coal at a specific price using swaps. An example of this deal is shown in Figure 6.

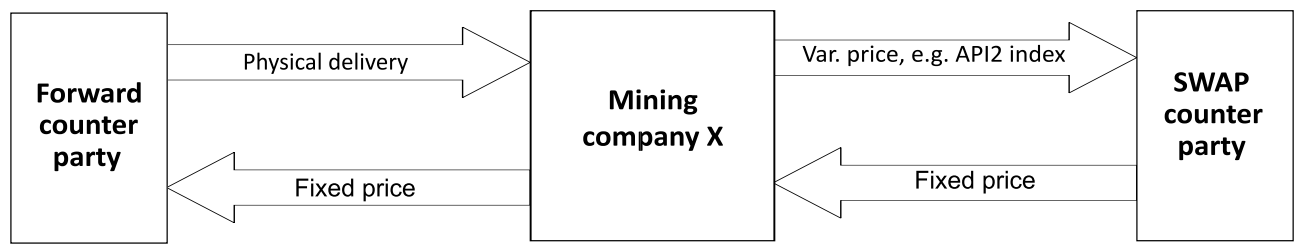

Fig. 6. A diagram of a commodity swap between a mining company and deal counterparts Source: own development

Rys. 6. Schemat swapu towarowego pomiędzy przedsiębiorstwem górniczym a partnerami transakcji

The item hedged is the volume of 1 million $\mathrm{Mg}$ of steam coal with the parameters required by the ARA market $(6,000 \mathrm{kcal} / \mathrm{kg}$ NAR, max sulphur $1 \%, 16 \%$ ash max).

In 2007, the mining company concluded a forward for delivering the above quantity of coal on July 1, 2008 at USD 90/Mg (price: spot CIF ARA 78 USD/Mg). It has decided to additionally hedge it with a swap.

The terms of the swap are as follows:

Volume: 250,000 tons

Variable price: spot CIF ARA on the settlement day

Fixed price: adopted for the forward

Payment frequency: quarterly from Jul. 1, 2007 to Jul. 1, 2008.

The cash flows from the deals are shown in Table 4.

The example presented applies to the period during which the price unpredictably rose on the global market. By concluding the forward and the appropriately designed swap, the mining company was able to increase its cash flows during the term of the contract 
by over USD 22 million, not accounting for the flows from the forward contract (USD 90 million).

The situation of the same swap contract when prices are falling (at a similar rate) is shown in Table 5.

When the prices are falling, the mining company has to pay the swap counterparty almost USD 38 million. Having performed under the forward, the company will receive

TABLE 4

Cash flows between the mining company and the swap counterparty

Przepływy finansowe pomiędzy przedsiębiorstwem górniczym a partnerem swap

\begin{tabular}{||c|c|c|c|c|c|c|}
\hline Date & Volume & $\begin{array}{c}\text { Fixed } \\
\text { price } \\
\text { [USD/Mg] }\end{array}$ & $\begin{array}{c}\text { Settlement } \\
\text { amount } \\
\text { [USD] }\end{array}$ & $\begin{array}{c}\text { Variable } \\
\text { price } \\
\text { [USD/Mg] }\end{array}$ & $\begin{array}{c}\text { Settlement } \\
\text { amount } \\
\text { [USD] }\end{array}$ & $\begin{array}{c}\text { Value of cash flows for } \\
\text { the mining company } \\
\text { [USD] }\end{array}$ \\
\hline \hline 1.07 .2007 & 250,000 & 90.0 & & 78.00 & & $-3,000,000$ \\
\hline 1.10 .2007 & 250,000 & 90.0 & $22,500,000$ & 102.00 & $19,500,000$ & $3,000,000$ \\
\hline 1.01 .2008 & 250,000 & 90.0 & $22,500,000$ & 130.00 & $25,500,000$ & $10,000,000$ \\
\hline 1.04 .2008 & 250,000 & 90.0 & $22,500,000$ & 138.00 & $32,500,000$ & $12,000,000$ \\
\hline 1.07 .2008 & & & $22,500,000$ & & $34,500,000$ & $22,000,000$ \\
\hline
\end{tabular}

Source: own development

Cash flows between the mining company and the swap counterparty - price fall

TABELA 5

Przepływy finansowe pomiędzy przedsiębiorstwem górniczym a partnerem swap - spadek cen

\begin{tabular}{||c|c|c|c|c|c|c||}
\hline Date & Volume & $\begin{array}{c}\text { Fixed price } \\
\text { [USD/Mg] }\end{array}$ & $\begin{array}{c}\text { Settlement } \\
\text { amount } \\
\text { [USD] }\end{array}$ & $\begin{array}{c}\text { Variable } \\
\text { price } \\
\text { [USD/Mg] }\end{array}$ & $\begin{array}{c}\text { Settlement } \\
\text { amount } \\
\text { [USD] }\end{array}$ & $\begin{array}{c}\text { Value of cash flows for } \\
\text { the mining company } \\
\text { [USD] }\end{array}$ \\
\hline \hline 1.07 .2007 & 250,000 & 90.0 & & 78.00 & & $-3,000,000$ \\
\hline 1.10 .2007 & 250,000 & 90.0 & $22,500,000$ & 53.80 & $19,500,000$ & $-9,050,000$ \\
\hline 1.01 .2008 & 250,000 & 90.0 & $22,500,000$ & 39.30 & $13,450,000$ & $-12,675,000$ \\
\hline 1.04 .2008 & 250,000 & 90.0 & $22,500,000$ & 37.00 & $9,825,000$ & $-13,250,000$ \\
\hline 1.07 .2008 & & & $22,500,000$ & & $9,250,000$ & $-37,975,000$ \\
\hline
\end{tabular}

Source: own development 
USD 90 million from its forward counterparty, so altogether, it generates a profit of almost USD 15 million (because if it were not for the forward, it would receive only USD 37 million for this volume on the market).

At this point it is worth noting that if such contracts are concluded in foreign currencies, it is also necessary to hedge the currency risk [cf. example in (Zawiła-Niedźwiecki et al. 2006)]. It is difficult to say whether the situation presented in the example will be repeated and it will be possible to benefit from the price increase to the same extent by taking a similar position in a swap. However, derivatives of this type can be a way to manage market risk. Apart from commodity swaps, mining companies can use FX swaps, IRS and other swaps described in the literature and commonly used in practice by various economic entities, depending on the type of risk that needs hedging (Stafford, Johnson 2008).

Detailed information on more complex issues related to the swap pricing and the accounting treatment, can be found in the literature such as (Miron, Swannell 1991; Dubofsky, Miller 2002; Geman 2005; Albanese, Camplieti 2006; International Financial... 2010).

The main advantages of swaps are:

- flexibility - the swap is create according to the specific needs of both parties,

- no requirements for a deposit - there is no need to freeze funds in security deposits, nor are there fees of other kinds (premiums) like those payable for other derivatives (futures, options),

- reducing the cost of funding - access to financial markets unattainable by traditional methods through foreign exchange contracts and interest rates (borrowing foreign currency according to the national interest rates),

- transaction costs - OTC swap ensures exchange of payment for any period (usually 10 years) - transaction costs are much lower than for short-term derivatives.

Disadvantages of swaps are the lack of swaps standardization and the OTC trade character. The swap involves also a significant credit risk associated with the insolvency of a swap counterparty. For liabilities arising from contracts such as futures and options guarantees are provided by a clearing house. As other derivatives, swaps are also related to market risk, operational risk and legal risk.

It should be kept in mind that a swap, just like any other financial instrument, can generate both high profits and huge losses. Therefore it is important to constantly monitor the situation on global markets and skilfully use the opportunities that arise by concluding appropriately structured contracts.

\section{Summary}

This article presents the newest group of derivatives: swaps. They allow companies to hedge specific risks associated with their business, e.g. of changes in interest rates, exchange rates, commodity prices, share prices, borrowers' creditworthiness. 
The rapid growth of the swap market, begun in 1980s and continuing to this day, is due to the multiple uses of these deals. Their advantage is their great flexibility stemming from the fact that they are traded OTC. Parties can freely set the terms of the contract and match them perfectly to their needs (Leszczyńska 2007).

Polish mining companies have a relatively short history of using derivatives to hedge various risks to their business. One exception is KGHM PolskaMiedź S.A., which, due to playing on the global copper market, has actively hedged risks for over 10 years. The relatively small proportion of hedging derivatives used by Polish hard-coal producers is mainly due to: the low proportion of exports in the total production sold, poorly developed risk management structures and the lack of experience in this field. In the light of the increased activity of Polish mining companies on the financial market and their interest in the field of hedging derivatives, this article proposes swaps as innovative instruments to hedge the hard coal price for the purposes of a mining company exporting a part of its production to the global market.

The paper is supported by Polish Ministry of Science and Higher Education as research project no N N524 360438

\section{REFERENCES}

Albanese C., Camplieti G., 2006 - Advanced Derivatives Pricing and Risk Management. Theory, Tools and Hands-On Programming Application. Elsevier Inc.

Bąk P., 2007 - Charakterystyka źródeł pozyskiwania kapitału i finansowania działalności przedsiębiorstw górniczych. Cz. 1, Źródła kapitału własnego. Gospodarka Surowcami Mineralnymi t. 23, z. 1.

Brzychczy E., 2011 - Wykorzystanie wybranych instrumentów finansowych transferu ryzyka w przedsiębiorstwach górniczych. Przegląd Górniczy, nr 9.

D u b o fs k y D.A., Mille r T.W., 2002 - Derivatives Valuation and Risk Management, Oxford University Press.

Geman H., 2005 - Commodities and Commodity Derivatives Modeling and Pricing for Agriculturals, Metals and Energy. John Wiley \& Sons Ltd.

Hull J., 2012 - Options, futures and other derivatives. Harlow: Pearson Education/Prentice Hall.

Instrumenty... 2001 - Instrumenty pochodne. Wprowadzenie. Praca zbiorowa. Oficyna Ekonomiczna, 2001.

J ajuga K., Jajuga T., 2007 - Inwestycje. Instrumenty finansowe, aktywa niefinansowe, ryzyko finansowe, inżynieria finansowa. Wydawnictwo Naukowe PWN, Warszawa.

J a me s T., 2003 - EnergyPriceRisk. Wyd. Palgrave.

Les zc zyń ska E., 2007 - Rynek kontraktów swap w Polsce. Wydawnictwo Narodowy Bank Polski.

Magda R., 2010 - Kontrakty terminowe w handlu węglem kamiennym na przykładzie nowojorskiej giełdy NYMEX. Przegląd Górniczy, t. 66, nr 9.

McDougal1 A., 2001 - Swapy. Oficyna Ekonomiczna, Oddział Polskich Wyd. Profesjonalnych Sp. z o.o., Kraków.

Miron P., Sw a n ne 11 P., 1991 - Pricing and Hediging Swaps, Euromoney Books.

Rozwój systemu finansowego w Polsce w 2010 roku. Narodowy Bank Polski, 2011.

S o p oćk o A., 2005 - Rynkowe instrumenty finansowe. Wydawnictwo naukowe PWN, Warszawa.

Sprawozdanie finansowe Grupy Kapitałowej KGHM Polska Miedź S.A. za okres 1.01.2010-30.06.2010, www.kghm.pl 
St afford Johns on R., 2008 - Introduction to Derivatives.Options, Futures, and Swaps. Oxford University Press, 2008.

Statistics - Bank for International Settlements, 2011.

Zawiła-Niedźwiecki et al. 2006 - Zawiła-Niedźwiecki J., Jadwis zczok J., Jadwis zczok A., Jadwis zczok A., 2006 - Znaczenie Giełdy Towarowej na rynku paliw i energii - przykłady zastosowań. Polityka Energetyczna t. 9, z. spec. Wyd. IGSMiE PAN, Kraków.

International Financial... 2010 - International Financial Reporting Standards: Derivative Accounting Considerations for Energy Transacting Activities. IAS 32/39 and IFRS 7. Materiały firmy Deloitte, 2010

Strony internetowe:

eGospodarka, 2005: http://www.finanse.egospodarka.pl/11328,Swap-towarowy-w-BRE-Banku, 1,48,1.html, http://www.platts.com/newsfeature/2008/forwardcurvecoal08/index

www.angloamerican.co.uk,

www.vale.com,

www.xstrata.com,

www.bhpbilliton.com/,

www.riotinto.com.

KONTRAKTY SWAP I MOŻLIWOŚCI ICH WYKORZYSTANIA W POLSKICH PRZEDSIĘBIORSTWACH GÓRNICZYCH

Słowa kluczowe

Kontrakty swap, górnictwo, węgiel kamienny, hedging

\section{Streszczenie}

Z prowadzeniem działalności gospodarczej wiąże się różnego rodzaju ryzyko, które znacząco może oddziaływać na wyniki ekonomiczne i produkcyjne osiągane przez dane przedsiębiorstwo. Jedną z możliwości zabezpieczenia się przed pewnymi typami ryzyka jest wykorzystanie odpowiednio skonstruowanych instrumentów pochodnych. W artykule zaprezentowano najmłodszą grupę tego typu kontraktów tj. swapy i zwrócono uwagę na możliwości wykorzystania tego typu kontraktów w krajowych przedsiębiorstwach z branży górnictwa węgla kamiennego, które część produkcji wprowadzają na rynek światowy.

W artykule opisano pokrótce charakterystykę i rodzaje kontraktów swap oraz rynek swapów w Polsce, którego pionierem był Polski Bank Rozwoju S.A. i pierwszy swap walutowy w 1992 roku. Od tego czasu w ofercie banków krajowych zaczęły pojawiać się również innego typu transakcje (swapy aktywów, walutowo-procentowe).

W przypadku polskich przedsiębiorstw górniczych wydobywających węgiel kamienny nie wykazują one jak dotąd aktywności na rynku swapów, co wynika z niewielkiej aktywności tych przedsiębiorstw na rynku instrumentów pochodnych.

W niniejszym artykule zaproponowano kontrakt swap jako innowacyjny instrument zabezpieczający cenę węgla kamiennego dla potrzeb przedsiębiorstwa górniczego eksportującego część wydobycia na rynek światowy.

W zaprezentowanym przykładzie przedsiębiorstwo górnicze zawierając kontrakt forward oraz odpowiednio skonstruowany swap towarowy mogło zabezpieczyć się jednocześnie przed spadkiem cen jak i wykorzystać dodatkowe przychody wynikające ze wzrostu cen na rynku światowym.

Oprócz swapów towarowych przedsiębiorstwa górnicze mogą sięgać po opisane w literaturze i powszechnie wykorzystywane w praktyce przez różne podmioty gospodarcze swapy walutowe, procentowe i inne, w zależności od rodzaju ryzyka wymagającego zabezpieczenia. Istotną zaletą tego typu kontraktów jest brak konieczności zamrażania środków w depozytach zabezpieczających i innych opłat (premia), ponoszonych przy innych instrumentach pochodnych (futures, opcje). 
102

PROPOSAL OF USING SWAPS BY HARD COAL MINING COMPANIES IN POLAND

\author{
Key words
}

Swaps, mining, hard coal, hedging

\title{
Abstract
}

Running a business entails various risks which can significantly impact the economic and production results achieved by a given enterprise. One way of hedging certain risks is to use appropriately designed derivatives. This article presents the newest group of these contracts, i.e. swaps, and focuses on how these contracts can be used by Polish mining companies from the hard coal mining sector selling a part of their output on the global market.

This article briefly characterises and presents types of swaps as well as the Polish swap market, pioneered by Polski Bank Rozwoju S.A. with the first FX swap of 1992. Since then, other types of transactions have also been included in the offering of domestic banks (assets swaps, cross-currency interest rate swaps).

Mining companies producing hard coal have not been active on the swap market yet because of their poor activity on derivative markets. This article proposes a swap as an derivative hedging the hard coal price for a mining company exporting a part of its production to the global market.

In the presented example, a mining company, by concluding a forward and an appropriately structured commodity swap, was able to both protect itself from a fall in the price and use additional gains due to prices rising in the global market.

Apart from commodity swaps, mining companies can use FX swaps, IRS and other swaps described in the literature and commonly applied in practice by various economic entities, depending on the type of risk that needs hedging. A significant advantage of this kind of contract is that there is no need to freeze funds in security deposits, nor are there fees of other kinds (premiums) like those payable for other derivatives (futures, options). 